UDC 615.322:547.913

\title{
THE COMPONENT COMPOSITION OF THE TRAGOPOGON ORIENTALIS VOLATILE CONSTITUENTS AND ITS BIOLOGICAL ACTIVITY
}

\author{
(c) Ye.M. Suleimen ${ }^{I^{*}}$, G.G. Sissengalieva ${ }^{1}$, M.Yu. Ishmuratova ${ }^{2}$, R.I. Jalmakhanbetova ${ }^{1,3}$ \\ 1 Institute of Applied Chemistry, L.N. Gumilyov Eurasian National University, \\ st. K. Satpayev, 2, Nur-Sultan, 010008 (Republic of Kazakstan), \\ e-mail: suleimen_em@enu.kz \\ ${ }^{2}$ E.A. Buketov Karaganda State University, st. University, 28, Karaganda, 100028 \\ (Republic of Kazakstan) \\ ${ }^{3}$ Kazak University of Technology and Business, st. K. Muhamedkhanova, 37A, \\ Nur-Sultan, 010008 (Republic of Kazakhstan)
}

The purpose of this study is the chemical investigation of the composition of Tragopogon orientalis volatile constituents (VC) and studying of its biological activity.

This article presents the results of research on the study of the chemical composition of species Tragopogon, as well as data of antiradical and cytotoxic activity. To study the dried and crushed aboveground part of the plant (leaves, flowers and stems) was taken. The raw material was collected in the flowering phase, growing in Northern Kazakstan. The VC was isolated from the plant of Tragopogon orientalis by hydrodistillation method on the Clevenger type apparatus. The chemical composition of the VC was determined by GC/MS.

The cytotoxic activity of the VC was determined by the survival rate of sea shrimp Artemia salina. VC of T. orientalis in all studied concentrations (1-10 $\left.\mathrm{mg} \mathrm{ml}^{-1}\right)$ exhibit acute lethal toxicity - all larvae die. Antiradical activity was determined by the method of colorimetry of free radicals (DPPH). The experimental results showed that the VC of $T$. orientalis at all tested concentrations $\left(0.1-1.0 \mathrm{mg} \mathrm{ml}^{-1}\right)$ exhibit low antiradical activity compared with the butylhydroxyanisole standard drug.

Keywords: Tragopogon orientalis L., volatile constituents, hydrodistillation method, GC/MS-analysis, component composition, biological activity.

\section{Introduction}

We continued our research in the field of studying the component composition of essential oils and their biological activity of plants of Kazakhstan [1-10] and selected Tragopogon orientalis L. as the object.

Tragopogon orientalis L. (Asteraceae Family) widespread in the territory Central, Eastern and Northern Kazakstan, Russia (Central Black Earth), grows in meadows and on dry slopes, in glades, sandy soils in pine forests $[11,12]$. This type is widely used in folk medicine as a choleretic, antiseptic, expectorant, antiscorbutic. In folk medicine in Siberia, the T. orientalis herb is used for hysteria, rheumatism, and gonorrhea [13], relieves headache, soothes and normalizes the state of health under stress [14, 15].

Suleimen Yerlan Melsuly - Candidate of Chem. Sciences, $\mathrm{PhD}$, Director of the Institute of Applied Chemistry, Professor of Chemistry Department of L.N. Gumilev, e-mail: suleimen_em@enu.kz

Sissengaliyeva Gulsana Galimzhankyzy - MSc of Chemistry, Leading Researcher at the Institute of Applied Chemistry, e-mail: sissengaliyevag@gmail.com

Ishmuratova Margarita Yulaevna - Candidate of biological Sciences, Professor of botany Department of Karaganda state University, e-mail: margarita.ishmur@mail.ru

Jalmakhanbetova Roza Ilemisovna - Doctor of Chem.

Sciences, Professor of Technology Department of Kazakh

University of technology and business,,

e-mail: rozadichem@mail.ru
Previously, its anatomical structure was studied [15], a number of flavonoids were detected spectrophotometrically [16]. As noted above, the plant is widely used in traditional medicine, and therefore we decided to investigate the component composition of the volatile compounds of the plant. In the literature we have not found any information on $T$. orientalis volatile compound, therefore, in this article we presented a study component composition its volatile constituents (VC).

\footnotetext{
* Corresponding author.
} 


\section{Experimental part}

Plant material. The elevated portion of raw materials T. orientalis (leaves, flowers and stems) was collected in the flowering phase in 20 June 2018 at surrounding of Astana city (under the bridge on Akzhol Street).

The well-developed samples of plants, without external signs of damages cut off with secateurs at the level of 4-5 cm from the surface of the soil; taking the top parts of stems, leaves and inflorescences. Collecting was carried out in the $1^{\text {st }}$ half of day from 9 to 11 o'clock. The cut-off raw materials were packed into paper package.

The collected raw material was dried and crushed. Samples of this plant are stored in the herbarium fund of the Faculty of Biology and Geography of Academician E.A. Buketov Karaganda State University. Voucher specimen is 1996.07.04.01.03.

Isolation of volatile constituents. VC was obtained from crushed dried masses $(125 \mathrm{~g})$ plants (without coarse stems) by the method of water distillation on the Clevenger apparatus within 2 hours [17]. Hexane is used as a trap for taking the $\mathrm{VC}$. Isolated $\mathrm{VC}$ was dried over $\mathrm{Na}_{2} \mathrm{SO}_{4}$, weighed and stored in sealed dark glass bottles in a cool and dark place at $5{ }^{\circ} \mathrm{C}$ temperature.

Analytical GC. GC/MS-analysis of T. orientalis VC made 3 times under the same conditions [8]. Determination of the composition of VC carried out on a gas chromatograph Clarus-SQ 8 with a mass spectrometric detector. Chromatographic conditions: capillary column RestekRxi ${ }^{\circledR}-1 \mathrm{~ms} 0.25 \mathrm{~mm} \times 30 \mathrm{~m} \times 0.25 \mu \mathrm{m}$; sample volume: $1.0 \mu$; carrier gas $\mathrm{He}$ (purity 99.9999); carrier gas rate: $1 \mathrm{ml} / \mathrm{min}$; stream division $1: 25$; t columns: $45^{\circ} \mathrm{C}(2 \mathrm{~min})$, rise $1.5^{\circ} \mathrm{C} / \mathrm{min}$ to $200^{\circ} \mathrm{C}$, then $15^{\circ} \mathrm{C} / \mathrm{min}$ to $280^{\circ} \mathrm{C}$, isothermal mode at $280^{\circ} \mathrm{C}$ for $10 \mathrm{~min}$; evaporator $\mathrm{t}-280^{\circ} \mathrm{C}$, mass spectrometry detector: $\mathrm{t}-240{ }^{\circ} \mathrm{C}, \mathrm{EI}+=70 \mathrm{eV}$; scan time from 4 to 120 minutes; ion scan mode $39-500 \mathrm{~m} / \mathrm{z}$. The percentage of components was calculated automatically, based on the peak areas of the total ion chromatogram. Components were identified by mass spectra and retention times using the NIST library. The retention time of the components was recalculated with respect to saturated hydrocarbons.

Cytotoxic activity. Separating funnel filled with $55 \mathrm{~mL}$ of artificial sea water and $200 \mathrm{mg}$ of Artemia salina eggs. Allowed standing for 3 days at the air supply until soft crustaceans gave the egg. One side of the tube covered with aluminum foil, and 5 minutes later, the larvae that are going on the bright side of the funnel, removed with Pasteur pipette.

20-40 larvae were placed in $990 \mu \mathrm{L}$ of seawater into each of the 24 micro titer plates. Dead larvae were counted using a microscope. Added $10 \mu \mathrm{L}$ of dimethylsulfoxide solution of $10 \mathrm{mg} \mathrm{ml}^{-1}$ sample. As a comparison, the drug actinomycin D or staurosporine was used. For a negative control $10 \mu \mathrm{L}$ was added only DMSO. After $24 \mathrm{~h}$ of incubation and further maintaining micro titer plates for 24 hours (to ensure immobility) counts the dead larvae by the microscope [18].

Mortality P determined by the following formula:

$$
P=\frac{A-N-B}{Z} \cdot 100 \%
$$

Where A - amount of dead larvae after $24 \mathrm{~h} ; \mathrm{N}$ - amount of larvae died before the test; $\mathrm{B}$ - the average amount of larvae died in a negative control; $\mathrm{Z}$ - the total amount of larvae.

Antiradical activity. Determination of antiradical activity of $\mathrm{VC}$ was carried out by the known technique of the colorimetry of free radicals based on reaction of the radical a 2,2-diphenyl-1-picrylhydrazil (DPPH) with standard of antioxidant $[19,20]$.

For determination of inhibition of DPPH to $0,1 \mathrm{~mL}$ of the test sample in the range of concentration of 0.1 ; $0.25 ; 0.5 ; 0.75 ; 1 \mathrm{mg} \mathrm{mL}^{-1}$ added $3 \mathrm{ml}$ of $6 \times 10^{-5} \mathrm{M}$ solution of radical. Centrifuge test tubes were in a support, wrapped in black polyethylene. After intensive mixing, solutions were left in the dark and after 30 minutes were measured absorbance of solutions at $520 \mathrm{~nm}$.

The values of antiradical activity (ARA) were calculated using the formula shown below:

$$
\text { ARA }(\%)=\left(\mathrm{A}_{0}-\mathrm{A}_{\mathrm{t}}\right) / \mathrm{A}_{0} \cdot 100 \%
$$

Where $\mathrm{A}_{0}$ - absorbance of control; $\mathrm{A}_{\mathrm{t}}$ - absorbance of the working sample.

The optical density of the investigated samples measured on a spectrophotometer Cary $60 \mathrm{UV}$-Vis. Antiradical activity of volatile constituents, we compared with butylhydroxyanisole (BHA). 


\section{The discussion of the results}

As can be seen from the table 1 and figure 1, the main components of the $\mathrm{VC}$ of $T$. orientalis are predominantly hydrocarbonsheneicosane $-15.6 \%$, (E)-15-heptadecenal $-11.2 \%$, hentriacontane $-7.9 \%$, nonacosane $-3.2 \%$, heptacosane $-2.9 \%, 3,7,11,15$-tetramethyl-2-hexadecen-1-ol $-2.7 \%$ and nonanal $-2.4 \%$.

These components, mostly hydrocarbons - typical of plants in the family Asteraceae, subfamily Lactucoideae, the genus Tragopogon belongs to them, are usually characterized by the presence of milky juice (latex) contained in the glandules, that was confirmed by earlier anatomical studies of a number of authors [15].

We carried out the determination of the cytotoxic activity of the T. orientalis volatile constituents. Determination of activity was carried out according to the well-known method of survival of marine shrimp Artemia salina [18]. Based on the experiment, it was found that the VC of T. orientalis in all tested concentrations (10, 5 and 1 $\mathrm{mg} \cdot \mathrm{ml}^{-1}$ ) exhibits acute lethal toxicity $(96 \%)$ - all larvae die (tabl. 2).

The determination of the antiradical activity of volatile constituents was carried out according to the method $[19,20]$. According to the results of the experiment, it was found that the VC of T. orientalis has low antiradical activity compared with butylhydroxyanisole (tabl. 3).

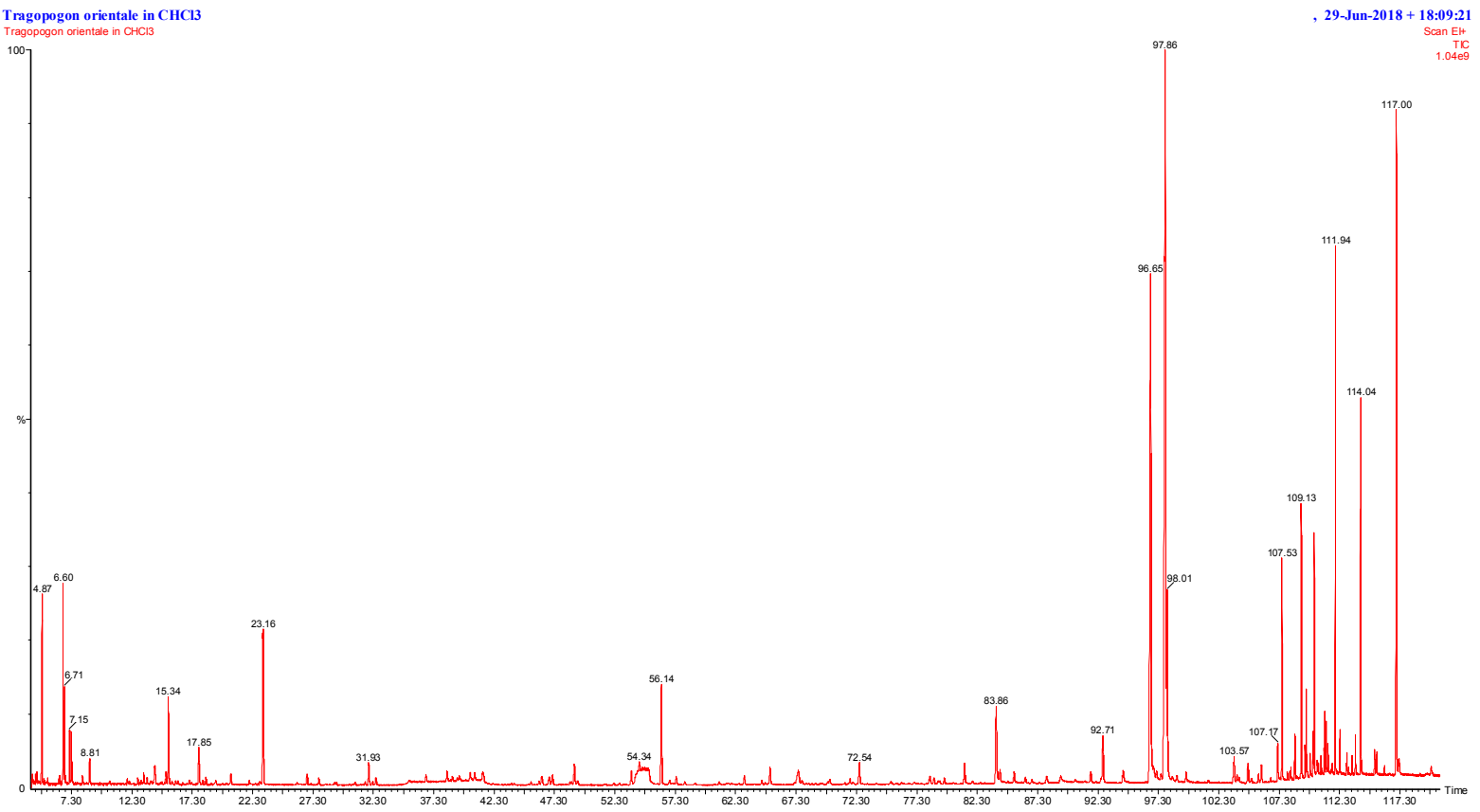

Fig. 1. Chromatogram of VC of T. orientalis

Table 1. Chemical composition of T. orientalis volatile constituents

\begin{tabular}{|c|c|c|c|c|c|c|}
\hline No & $\begin{array}{c}\text { Retention } \\
\text { time }\end{array}$ & $\overline{\mathrm{R}_{\text {lit }}}$ & $R_{\text {calc }}$ & Component & $\begin{array}{c}\text { Probabil- } \\
\text { ity }\end{array}$ & Content, $\%$ \\
\hline 1 & 2 & 3 & 4 & 5 & 6 & 7 \\
\hline 1 & 4.866 & 800 & 798 & Octane & 838 & $1.5 \pm 0.2$ \\
\hline 2 & 6.605 & $854 \pm 3$ & 843 & (E)-2-Hexanal & 942 & $1.4 \pm 0.2$ \\
\hline 3 & 6.711 & $857 \pm 3$ & 845 & (Z)-Hex-3-en-1-ol & 940 & $0.7 \pm 0.1$ \\
\hline 4 & 7.148 & $868 \pm 4$ & 857 & cis-2-Hexene-1-ol & 930 & $0.4 \pm 0.1$ \\
\hline 5 & 7.313 & $846 \pm 8$ & 861 & Isohexyl alcohol & 870 & $0.4 \pm 0.1$ \\
\hline 6 & 8.211 & $891 \pm 2$ & 884 & 2-Heptanone & 805 & $0.1 \pm 0.1$ \\
\hline 7 & 8.809 & $901 \pm 2$ & 899 & Heptanal & 847 & $0.3 \pm 0.1$ \\
\hline 8 & 13.3 & $979 \pm 2$ & 969 & 1-Octen-3-on & 883 & $0.1 \pm 0.1$ \\
\hline 9 & 15.12 & $1003 \pm 2$ & 997 & $n$-Caprylic aldehyde & 921 & $0.2 \pm 0.1$ \\
\hline 10 & 15.336 & $1005 \pm 2$ & 1000 & cis-3-Hexenyl acetate & 948 & $1.1 \pm 0.2$ \\
\hline 11 & 17.853 & $1045 \pm 4$ & 1033 & Benzaldehyde & 924 & $0.6 \pm 0.1$ \\
\hline 12 & 18.436 & $1038 \pm 2$ & 1040 & $\beta$-cis-Ocimen & 894 & $0.1 \pm 0.1$ \\
\hline 13 & 20.494 & $1071 \pm 3$ & 1067 & 1-Octanol & 787 & $0.2 \pm 0.1$ \\
\hline 14 & 23.162 & $1104 \pm 2$ & 1101 & Nonanal & 924 & $\mathbf{2 . 4} \pm 0.3$ \\
\hline 15 & 27.777 & $1162 \pm 3$ & 1152 & (E)-2-Nonenal & 893 & $0.1 \pm 0.1$ \\
\hline
\end{tabular}


End of table 1

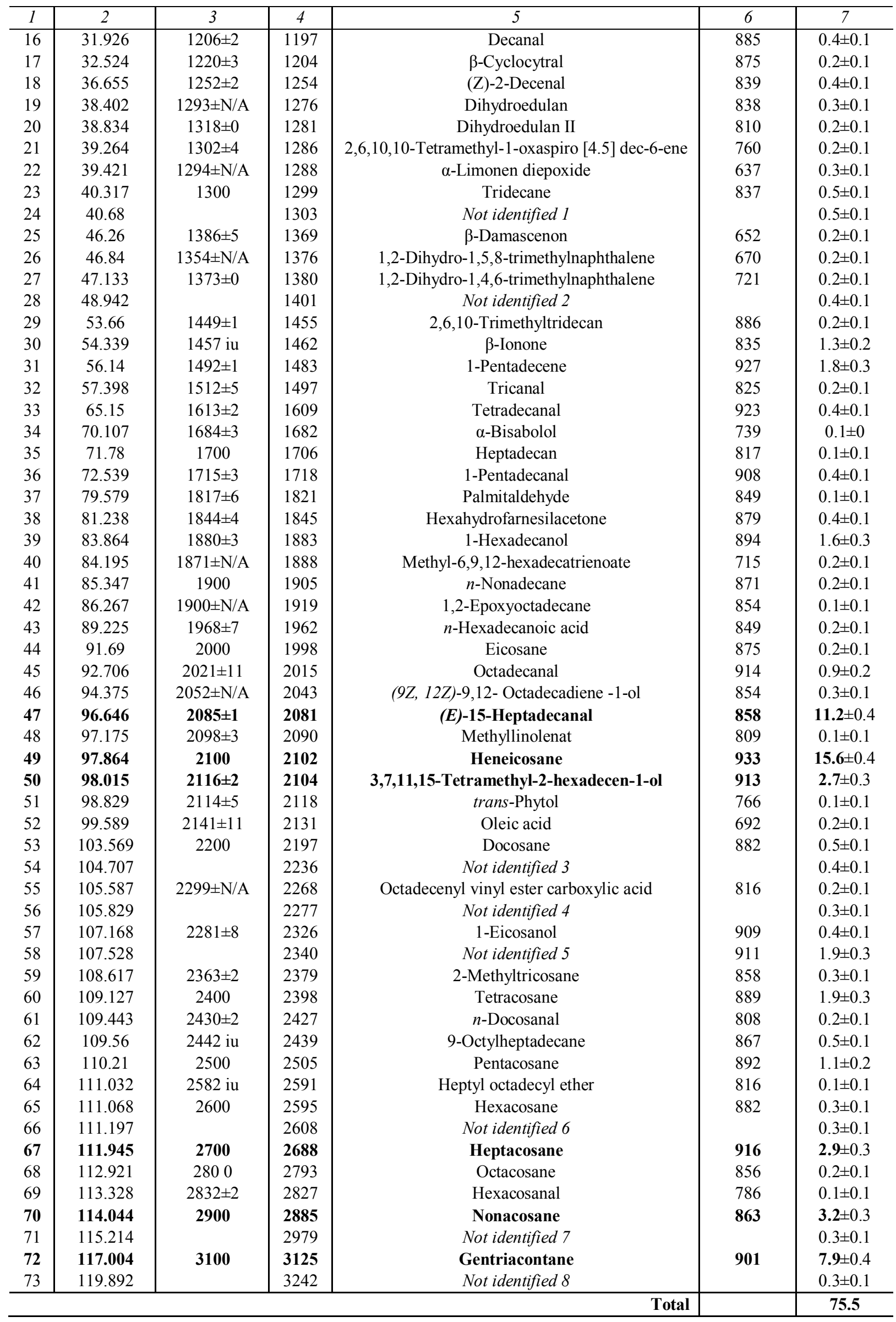


Table 2. Cytotoxic activity of $T$. orientalis volatile constituents

\begin{tabular}{|c|c|c|c|c|c|c|c|c|c|}
\hline \multirow[t]{2}{*}{$\begin{array}{c}\text { Paral- } \\
\text { lel }\end{array}$} & \multicolumn{2}{|c|}{$\begin{array}{l}\text { Number of lar- } \\
\text { vae in control }\end{array}$} & \multicolumn{3}{|c|}{$\begin{array}{c}\text { Number of larvae in the } \\
\text { sample }\end{array}$} & \multirow{2}{*}{$\begin{array}{l}\% \text { of surviving } \\
\text { larvae in con- } \\
\text { trol }\end{array}$} & \multirow{2}{*}{$\begin{array}{c}\% \text { of surviving } \\
\text { larvae in the } \\
\text { sample }\end{array}$} & \multirow[t]{2}{*}{$\begin{array}{c}\text { Mortality } \\
\text { A, } \%\end{array}$} & \multirow{2}{*}{$\begin{array}{c}\text { Presence of } \\
\text { neurotoxicity, } \\
\%\end{array}$} \\
\hline & surv. & dead & surv. & dead & par. & & & & \\
\hline \multicolumn{10}{|c|}{$10 \mathrm{mg} \mathrm{ml}^{-1}$} \\
\hline Med. & 24 & 1 & 0 & 25 & 0 & 96 & 0 & 96 & 0 \\
\hline \multicolumn{10}{|c|}{$5 \mathrm{mg} \mathrm{ml}^{-1}$} \\
\hline Med. & 24 & 1 & 0 & 28 & 0 & 96 & 0 & 96 & 0 \\
\hline \multicolumn{10}{|c|}{$1 \mathrm{mg} \mathrm{ml}^{-1}$} \\
\hline Med. & 24 & 1 & 0 & 27 & 0 & 96 & 0 & 96 & 0 \\
\hline
\end{tabular}

Table 3. Antiradical activity (\%) of T. orientalis volatile constituents in different concentrations

\begin{tabular}{l|c|c|c|c|cc}
\hline \multirow{2}{*}{ Test substances } & \multicolumn{5}{c}{ Concentration of solutions $\left(\mathrm{mg} \mathrm{ml}^{-1}\right)$} \\
\cline { 2 - 7 } & 0.1 & 0.25 & 0.5 & 0.75 & 1.0 \\
\hline Butylhydroxyanisole (BHA) & 80.82 & 81.23 & 80.30 & 83.08 & 83.88 \\
VC of Tragopogon orientalis (Torient-1) & 6.13 & 6.71 & 7.48 & 7.62 & 7.87 \\
\hline
\end{tabular}

\section{Conclusion}

Thus, we first investigated the component composition of the volatile constituents of $T$. orientalis, as well as studied cytotoxic and antiradical activity. As a result of researches it is revealed that the volatile constituents of $T$. orientalis show high cytotoxic and low antiradical activity.

\section{Acknowledgments}

Authors thank Dr, Associated Professor Iskakova Zh.B. from Kazak University of Technology and Business (Nur-Sultan, Kazakstan) for help in investigation of cytotoxic and antiradical activities.

\section{References}

1. Sampietro D.A., Lizarraga E.F., Ibatayev Zh.A., Omarova A.B., Suleimen Ye.M., Catalán C.A.N. Natural Product Research: Formerly Natural Product Letters, 2016, vol. 30, pp. 1950-1955. DOI: 10.1080/14786419.2015.1091453.

2. Suleimen Ye.M., Ibatayev Zh.A., Iskakova Zh.B., Ishmuratova M.Yu. Chem. Nat. Compd., 2016, vol. 52, no. 1, pp. 171-172. DOI: 10.1007/s10600-016-1583-x.

3. Suleimen Ye.M., Ibataev Zh.A., Iskakova Zh.B., Ishmuratova M.Yu., Ross S.A., Martins C.H.G. Chem. Nat. Compd., 2016, vol. 52, no. 1, pp. 173-175. DOI: 10.1007/s10600-016-1584-9.

4. Kirillov V., Stikhareva T., Suleimen Ye., Serafimovich M., Kabanova S., Mukanov B. Natural Product Research: Formerly Natural Product Letters, 2016, vol. 31, pp. 117-123. DOI: 10.1080/14786419.2016.1214832.

5. Sampietro D.A., de los A. Gomez A., Jimenez C.M., Lizarraga E.F., Ibatayev Zh.A., Suleimen Ye.M., Catalán C.A. Natural Product Research: Formerly Natural Product Letters., 2017, vol. 31, pp. 1464-1467. DOI: $10.1080 / 14786419.2016 .1258560$.

6. Suleimen E.M., Myrzagaliyeva A.B., Ibatayev Zh.A., Iskakova Zh.B., Samarkhanov T.N., Medeubayeva B.Z. Khimiya Rastitel'nogo Syr'ya, 2016, no. 4, pp. 83-88. DOI: 10.14258/jcprm.2016041340.

7. Suleimen E.M., Gorovoi P.G., Dudkin R.V., Ibataev Zh.A., Ross S.A. Chem. Nat. Compd., 2017, vol. 53, no. 2, pp. 388-389. DOI: 10.1007/s10600-017-2001-8.

8. Zhunusova M.A., Suleimen Ye.M., Iskakova Zh.B., Ishmuratova M.Yu., Abdullabekova R.M. Chem. Nat. Compd., 2017, vol. 53, no. 4, pp. 775-777. DOI: 10.1007/s10600-017-2118-9.

9. Suleimen Ye.M., Zhanzhaxina A.Sh., Sissengalieva G.G., Iskakova Zh.B., Ishmuratova M.Yu. Chem. Nat. Compd., 2018, vol. 54, no. 3, pp. 595-596. DOI: 10.1007/s10600-018-2420-1.

10. Suleimen Ye.M., Iskakova Zh.B., Dudkin R.V., Gorovoi P.G. Chem. Nat. Compd., 2018, no. 3, pp. 507-508. DOI: 10.1007/s10600-018-2421-0.

11. Pavlov N.V. Flora Kazakhstana. [Flora of Kazakhstan]. Alma-Ata, 1966, 450 p. (in Russ.).

12. Kamyshev N.S. Flora Tsentral'nogo Chernozem'ya i yeye analiz. [Flora of the Central Black Earth Region and its analysis]. Voronezh, 1978, 116 p. (in Russ.).

13. Budantseva A.L., Lesiovskaya E.E. Dikorastushchiye poleznyye rasteniya Rossii. [Wild useful plants of Russia]. St. Petersburg, 2001, 130 p. (in Russ.).

14. Chuhno V., Rozhko N. Lekarstvennyye rasteniya. Illyustrirovannyy entsiklopedicheskiy slovar'. [Medicinal plants. Illustrative encyclopedic dictionary]. Moscow, 2007, 768 p. (in Russ.).

15. Bubenchikova V.N., Trembalya Ya.S., Prokhorova S.A. Nauchnyye vedomosti Belgorodskogo gosudarstvennogo universiteta. Seriya: Yestestvennyye nauki, 2011, vol. 104, no. 15-2, pp. 82-88. (in Russ.). 
16. Bubenchikova V.N., Prokhorova S.A. Vestnik novykh meditsinskikh tekhnologiy, 2011, vol. 18, no. 3, pp. 272-273. (in Russ.).

17. Gosudarstvennaya farmakopeya SSSR. [State Pharmacopoeia of the USSR]. Moscow, 1990, vol. 2, 400 p. (in Russ.).

18. Suleimenov Ye.M. Chem. Nat. Compd., 2009, vol. 45, no. 5, pp. 710-711. DOI: 10.1007/s10600-009-9423-x.

19. Sawant O., Kadam V.J., Ghosh R. Journal of Herbal Medicine and Toxicology, 2009, vol. 3, pp. 39-44.

20. Sisengalieva G.G., Suleimen Ye.M., Ishmuratova M.Yu., Iskakova Zh.B., Van Hecke K. Chem. Nat. Compd., 2015, vol. 51, no. 3, pp. 544-547. DOI: 10.1007/s10600-015-1337-1.

Received December 21, 2018

Revised February 18, 2019

Accepted April 9, 2019

For citing: Suleimen Ye.M., Sissengalieva G.G., Ishmuratova M.Yu., Jalmakhanbetova R.I. Khimiya Rastitel'nogo Syr'ya, 2019, no. 3, pp. 103-108. DOI: 10.14258/jcprm.2019034859. 